TAO, Vol. 16, No. 4, 897-908, October 2005

\title{
Gas Hazard Induced by Methane and Hydrogen Sulfide Seepage in the NW Peloponnesus Petroliferous Basin (Greece)
}

\author{
Giuseppe Etiope ${ }^{1, *}$, George Papatheodorou ${ }^{2}$, Dimitris Christodoulou ${ }^{2}$, \\ Paolo Favali ${ }^{1}$ and George Ferentinos ${ }^{2}$
}

(Manuscript received 10 November 2004, in final form 20 July 2005)

\begin{abstract}
Gas seeps along the Ionian coast of the northwestern Peloponnesus (Greece) constitute a severe hazard for humans and buildings. Methane, migrating from deep carbonatic hydrocarbon reservoirs, is seeping in amounts potentially explosive and hydrogen sulfide is beyond the levels that induce toxicological diseases and lethal effects. The seeps are related to intense methane microseepage in the surrounding areas (orders of $10^{1}$ to $10^{5} \mathrm{mg} \mathrm{m}^{-2} \mathrm{~d}^{-1}$ over $10^{4} \mathrm{~m}^{2}$ areas, at least) and produce significant $\mathrm{CH}_{4}-\mathrm{H}_{2} \mathrm{~S}$ enrichments in the atmosphere. Gas-charged sediments in the seafloor and bubbling plumes present a high risk for offshore constructions and facilities.
\end{abstract}

(Key words: Methane, Hydrogen sulfide, Seeps, Microseepage, Petroleum)

\section{INTRODUCTION}

Hazards for humans induced by endogenous gas emissions are frequently reported and studied in geothermal and volcanic areas (e.g., Baxter et al. 1999, and references therein; Etiope et al. 2005; Lee et al. 2005; Pecoraino and Giammanco 2005), where the gas is typically composed of toxic, asphyxiating, inorganic compounds (e.g., $\mathrm{CO}_{2}, \mathrm{H}_{2} \mathrm{~S}, \mathrm{SO}_{2}, \mathrm{CO}$ ) or radioactive elements $(\mathrm{Rn})$, generally produced in high-temperature (thermo-metamorphic or magmatic) environments with uranium-rich rocks. Less studied are the hazards induced by gas from "low-temperature" coal- or hydrocarbon-prone sedimentary basins; in these cases the focus of hazards is on the negative impact on mining and offshore oil industries (Flores 1998; Etiope et al. 2002). Hazards for humans from onshore natural gas seeps are much less investigated. Nevertheless gas seepage, related to shallow or deep, biogenic or thermogenic

\footnotetext{
1 INGV, Istituto Nazionale di Geofisica e Vulcanologia, Sezione Roma 2, ITALY

2 Department of Geology, University of Patras, GREECE

* Corresponding author address: Dr. Giuseppe Etiope, INGV, Istituto Nazionale di Geofisica e Vulcanologia, Sezione Roma 2, ITALY; E-mail: Etiope@ingv.it
} 
hydrocarbon reservoirs, is widespread throughout the Alpine-Himalayan, Pacific Ocean and Caribbean sedimentary belts and constitute a major source of atmospheric methane (Etiope and Klusman 2002; Etiope 2005).

In this paper we present the first data on impressive onshore and offshore emissions of methane $\left(\mathrm{CH}_{4}\right)$ and hydrogen sulfide $\left(\mathrm{H}_{2} \mathrm{~S}\right)$ along the coast of a petroleum-bearing zone in western Peloponnesus (Greece), part of the Mediterranean region oil province. These seeps constitute a severe risk for humans and buildings.

Two gas surveys were performed in April and July 2004 at the three main seeping areas: Killini, Katakolo and Kaiafas. These seeps had never been analysed before, apart from one in the Katakolo area (Kamberis et al. 2000). Our surveys are based on an integrated approach in which all the different surface sub-systems (soil-gas, exhalation flux, gas vents, groundwater, atmosphere) are analysed: specifically, the surveys included measurements of methane flux from the soil to the atmosphere (microseepage), analysis of gas concentration in atmospheric air above the soil, in offshore and onshore vents and water springs.

\section{GEOLOGICAL SETTING}

The three study areas, Killini Peninsula, Katakolo Peninsula and Kaiafas, are located in the NW Peloponnesus, 50 to $60 \mathrm{~km}$ east of the north-western end of the Hellenic subduction zone (Figs. 1a, b). An active subduction of the Ionian oceanic crust has been taking place beneath the outer Hellenic Arc, since Late Neogene (Monopolis and Bruneton 1982). Three NW-SE trending tectono-stratigraphic zones are defined in the External Hellenides, from west to east: the pre-Apulian, the Ionian and the Gavrovo zone (Fig. 1a). Sediments accumulated in the basins which were formed in the tectono-stratigraphic zones, during the Neogene and the Quaternary (Zelilidis et al. 1998). Deep seismic data show that the development of Neogene basins was controlled by the Gavrovo thrust sheet propagating to the west (Kamberis et al. 2000). As a result of this orogenic migration an asymmetric basin (foredeep) in front of the thrust belts and piggy-back basins on the propagated thrust sheets were developed. JurassicEocene carbonates and thick clastic sequences are separated by Triassic evaporites (mainly anhydrites), which penetrated the carbonate series through diapiric movements related to the thrusting of the Gavrovo nappes. Oil-gas fields occur in deep carbonates and clastic sequences from Jurassic to Eocene (Kamberis et al. 2000). Deep faults, likely related to salt tectonics, act as preferential pathways for the natural gas' upward migration producing gas seeps off and on the Ionian coast (Fig. 2).

\section{THE GAS SEEPS}

Killini and Kaiafas seeps are associated to sulphur water springs, which constitute local tourist attractions with spas called "thermal" baths. The term "thermal" is however not appropriate as the water is not warm $\left(22-23^{\circ} \mathrm{C}\right)$ and has no relations with any geothermal environment (the Ionian zone is a "cold" sedimentary basin). In this respect Killini and Kaiafas represent a rare typology of sulphur springs, where the carrier gas is methane (and not carbon 


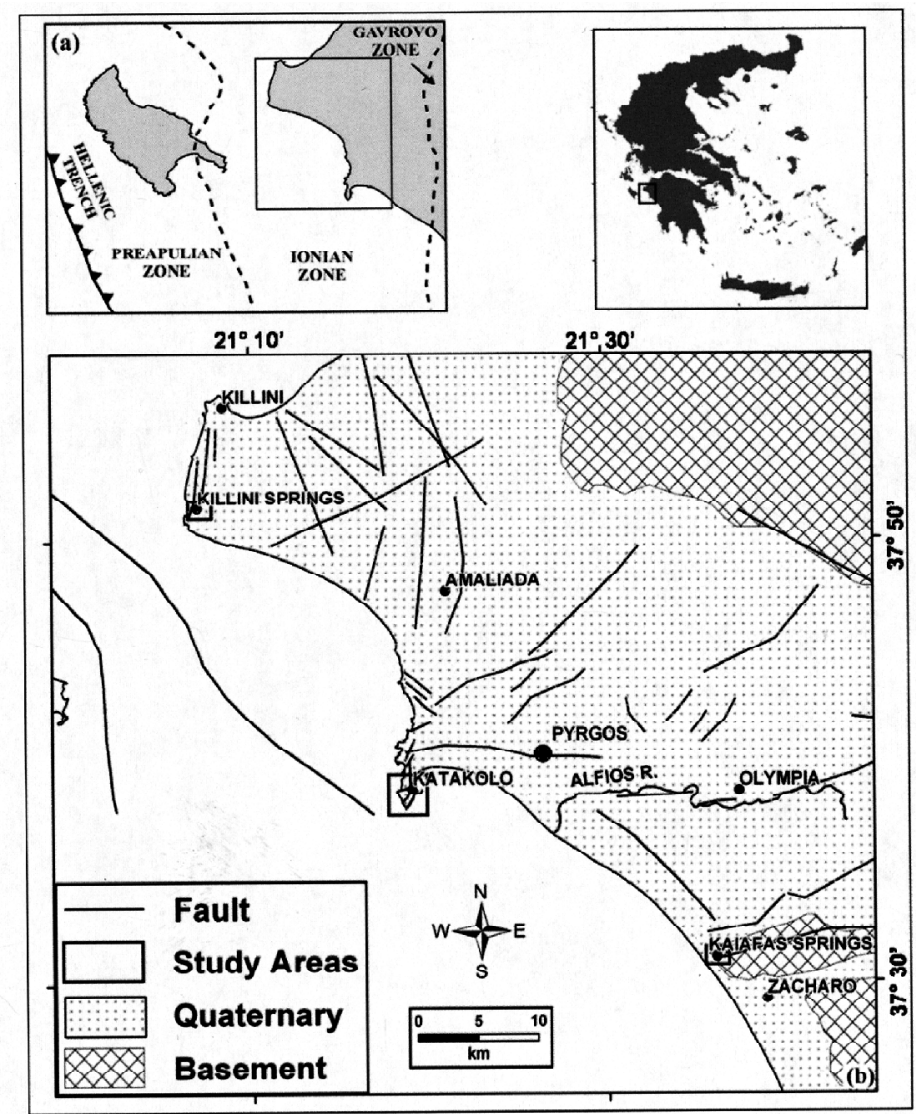

Fig. 1. (a) General map showing the position of the study area in relation to the Hellenic Trench and the three tectono-stratigraphic zones. Top-right: location in Greece. (b) General tectonic setting of NW Peloponnesus (after Brooks and Ferentinos 1984, Koukouvelas et al. 1996; Kamberis et al. 2000; Lekkas et al. 2000).

dioxide) and the sulphur compounds are not produced by geothermal processes but by petroleum-generation processes (Hunt 1996).

Katakolo seeps occur offshore and onshore of the local tourist harbour (Figs. 2, 3). Offshore bubbling plumes are widespread throughout the harbour docks (Fig. 3b). Bubbles are visible from the wharf over a wide area (order of $10^{3} \mathrm{~m}^{2}$ ); divers have found bubbles of the order of $10-20 \mathrm{~cm}$ in diameter issuing from cracks in the seabed covered by white bacterial mats (Fig. 4). Onshore seeps have penetrated and damaged the asphalt pave of the harbour zone at two main points, the Duty Free Shop building (Katakolo is a port of call for tourist cruise ships) and at the entrance of the custom premises (Figs. 3b, 5). The seeps have a heavy rotten-egg smell. In 1972 a flame blew-out from the pavement of the main wharf destroying a pole. 


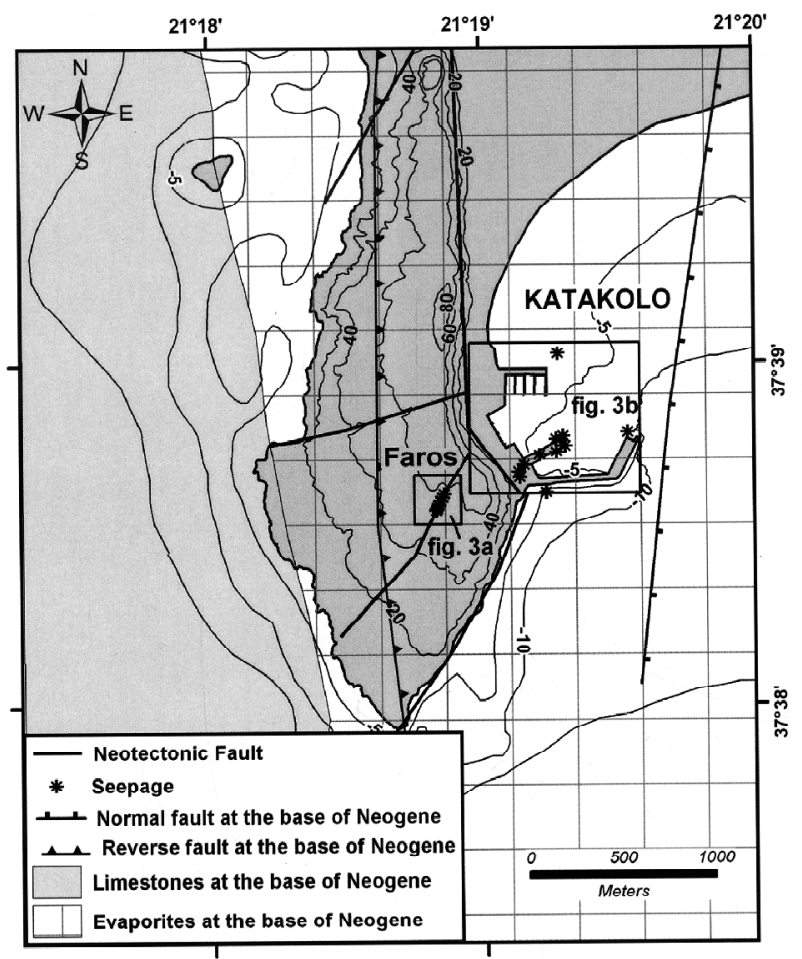

Fig. 2. Structural map of Katakolo Peninsula showing onshore and offshore seepages and Faros macroseep; contour lines: seafloor depth (m); (structural data after Kamberis et al. 2000).

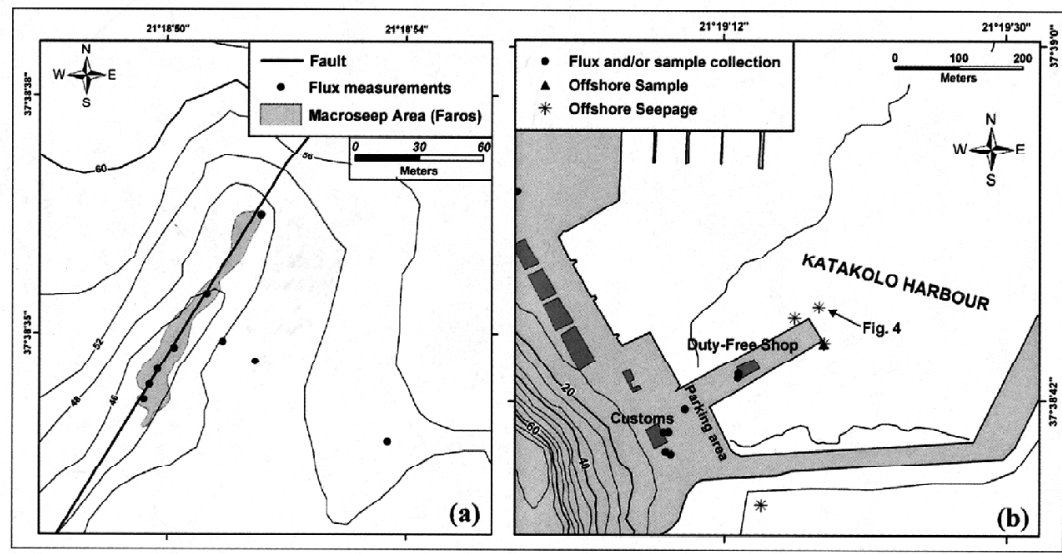

Fig. 3. Detailed maps showing: (a) flux measurement locations at Faros macroseep; (b) onshore and offshore seepages, flux measurement and gas sample locations at Katakolo harbour. Contour lines: seafloor depth (m). 


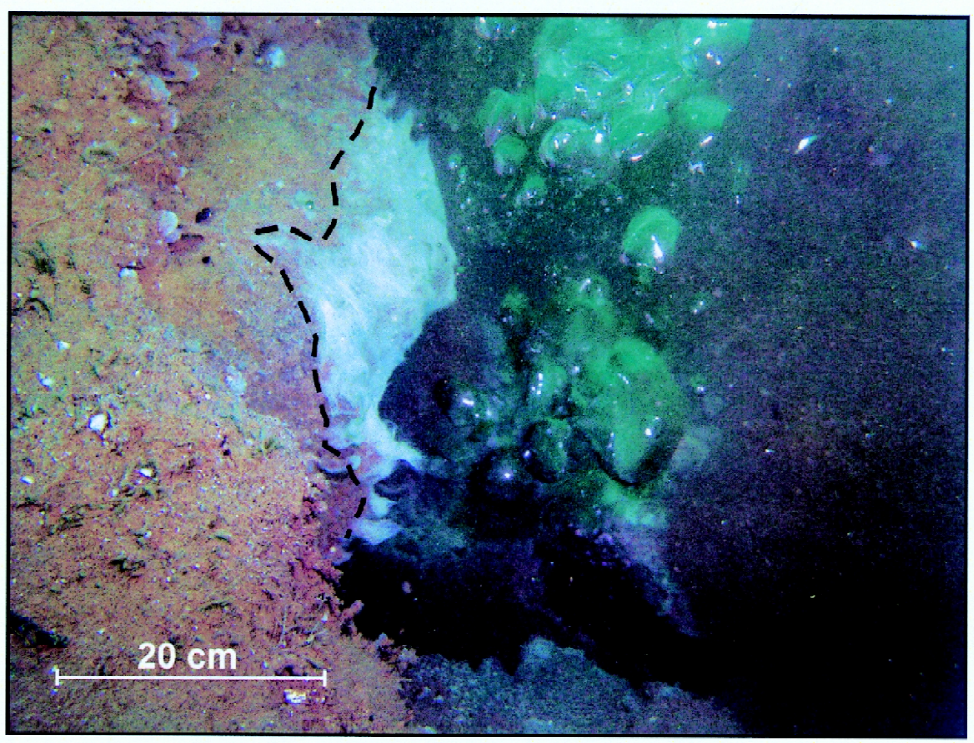

Fig. 4. Gas bubbles rising from the seafloor at Katakolo harbour (see location in Fig. 3b). Bubbles emanate from a small crack in the carbonate-cemented seafloor. A small patch of white-coloured mats is marked by broken lines.
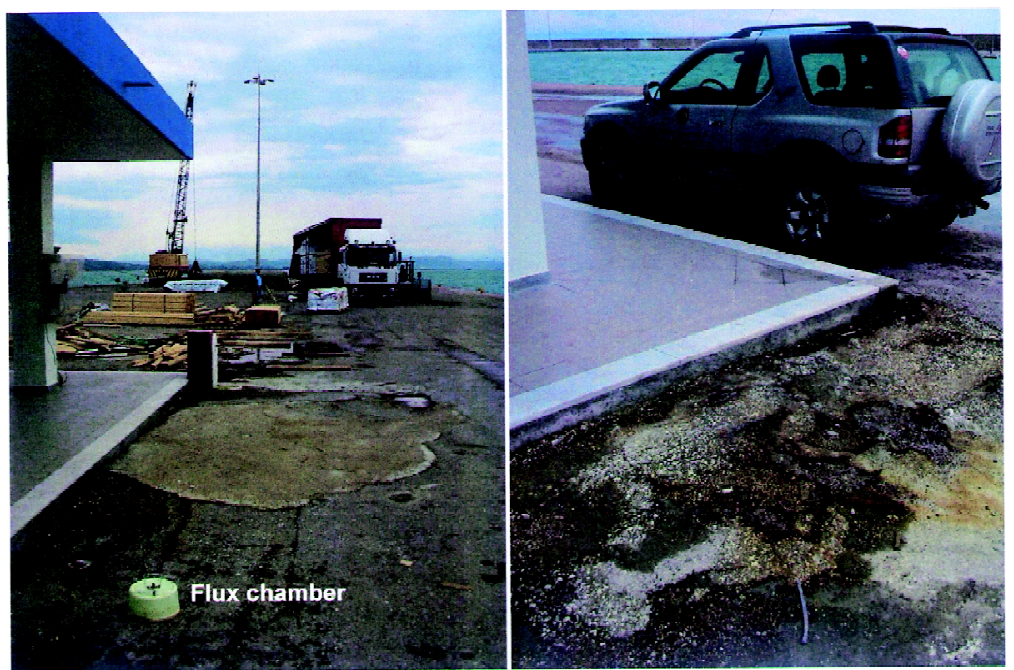

Fig. 5. Seeps in the Katakolo harbour. Left photo: measurement of gas flux (by closed-chamber) from shattered asphalt pavement on the main wharf; a cement plate was spread out to cover the cracks produced by the 1972 explosion. Right photo: $\mathrm{H}_{2} \mathrm{~S}$ rich seepage outside of the duty free shop. 


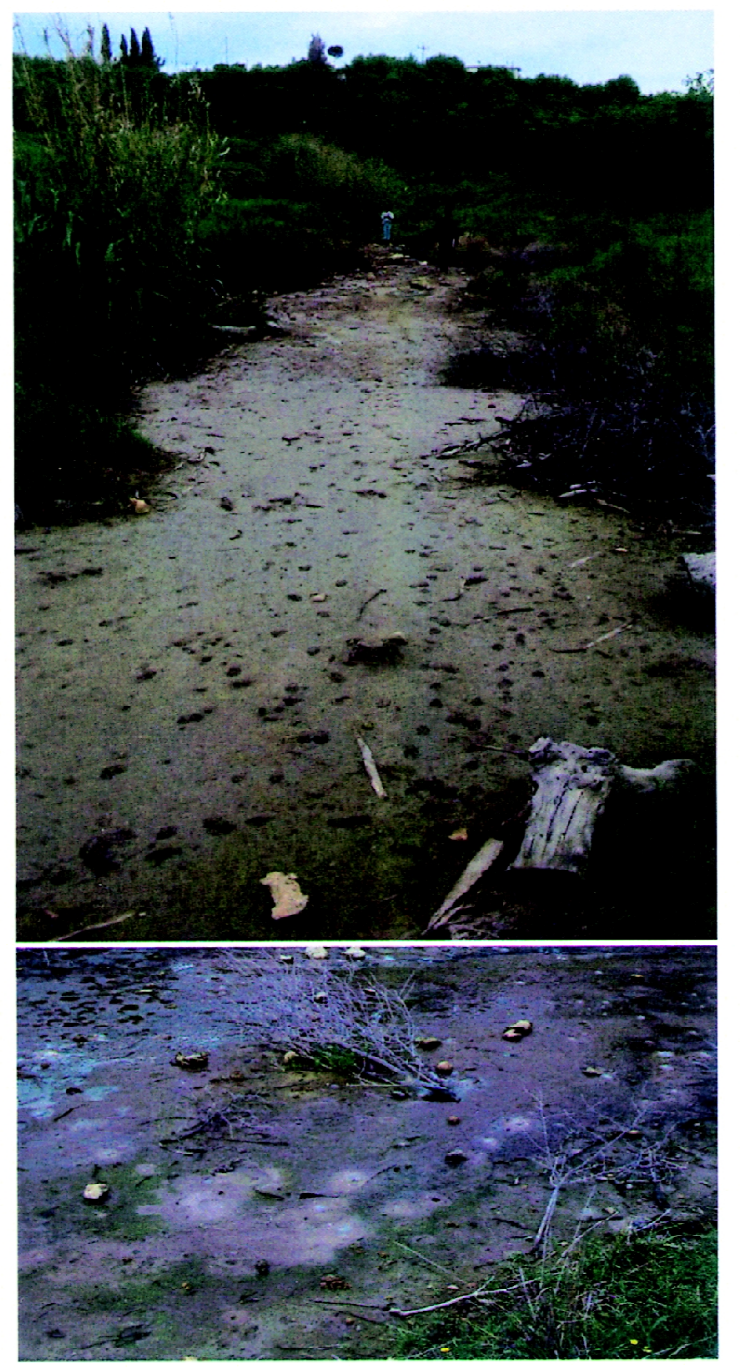

Fig. 6. Faros macroseep (Katakolo). Gas seepage is distributed along the trace of a NE-SW fault crossing the Katakolo pensinsula (see Fig. 2) and produces bubbling vents, natural fire flames and diffuse degassing from soil.

Other impressive onshore Katakolo seeps are located about $0.5 \mathrm{~km}$ northward of the harbour, at a site named "Faros" (Figs. 3a, 6). Here is an $800-\mathrm{m}^{2}$-wide area with highly degassing soil and bubbling pools with oil leakage. Some vents can be easily ignited with a lighter producing flames about $20 \mathrm{~cm}$ in height. The seep cannot be considered a mud volcano, as local people call it, because there is no actual mud emission and therefore any conical morphology. However it seems to be the biggest onshore methane seep ever reported in Greece. We will call it simply "Faros macroseep". 


\section{METHODOLOGY}

Microseepage flux was measured by closed chamber method (Klusman et al. 2000; Etiope et al. 2004) at Killini (19 points), Katakolo harbour (9 points) and Faros macroseep (9 points). Gas accumulated in a 10-L chamber was collected two times into syringes at time intervals varying from 5 to $20 \mathrm{~min}$ after the deployment of the chamber. Methane analyses were performed in duplicate in the same day by portable gas chromatograph with FID detector (Autofim II, Telegan; detection limit $0.1 \mathrm{ppmv}$, accuracy $4-5 \%$ ). Flux measurement reproducibility is within $13 \%$ and $20 \%$ for fluxes below and above $5,000 \mathrm{mg} \mathrm{m}^{-2} \mathrm{~d}^{-1}$, respectively. The portable FID was also used as a sniffer to record methane concentration in atmospheric air within 50 $\mathrm{cm}$ above the soil surface. All the sites were monitored throughout tens of square meters by 60 recordings in total. Two offshore gas vents (bubble plumes $10 \mathrm{~m}$ deep) were sampled by divers at Katakolo harbour. Gas bubbles were easily collected in $200 \mathrm{cc}$ sealed glass bottles, at seabed, with silicon septa and aluminium caps. Onshore gas vents were collected at Katakolo harbour, Faros macroseep and Killini bubbling pools using inverted funnels or chambers and the gas was stored in the $200 \mathrm{cc}$ glass bottles.

Groundwater was collected from Killini and Kaiafas springs, at the main discharge points. Kaiafas spring is, however, a pool inside a cave, therefore some degassing has to be expected into the cave air. Water was stored in $200 \mathrm{cc}$ glass bottles with silicon septa and aluminium caps. Gas was extracted by head-space method.

This paper, being focused on gas hazards, reports only data of $\mathrm{CH}_{4}$ and $\mathrm{H}_{2} \mathrm{~S}$, although a wider spectrum of gaseous compounds were analysed; they will be discussed elsewhere. $\mathrm{CH}_{4}$ and $\mathrm{H}_{2} \mathrm{~S}$ are analysed by gas chromatography (Carle AGC 100 - 400 TCD-FID GC; detection limit: $\mathrm{CH}_{4}: 10$ ppmv; $\mathrm{H}_{2} \mathrm{~S}: 150$ ppmv; accuracy $2 \% ; 10 \%$ at the detection limit) at the Isotech Labs Inc. (Illinois, USA). Rapid on-site analyses were also made for $\mathrm{CH}_{4}$ by the same portable GC-FID used for microseepage, and for $\mathrm{H}_{2} \mathrm{~S}$ by RAE colorimetric tubes and sampling pump (accuracy $<10 \%$; detection limit $0.2 \mathrm{ppmv}$ ).

\section{RESULTS}

Table 1 shows the microseepage flux measured at Killini and Katakolo. At Killini the highest flux, in the order of $10^{2}-10^{3} \mathrm{mg} \mathrm{m}^{-2} \mathrm{~d}^{-1}$, occurs close to the main spring, picked up by a borehole. Tens to hundreds $\mathrm{mg} \mathrm{m}^{-2} \mathrm{~d}^{-1}$ are emitted around the bubbling pools. Far from the spring and pools (> $100 \mathrm{~m}$ ) the microseepage drops to a few tens or units of $\mathrm{mg} \mathrm{m}^{-2} \mathrm{~d}^{-1}$ down to negative values. Katakolo seepage is up to two orders of magnitude higher than that in Killini. The values reach 285000 and $165000 \mathrm{mg} \mathrm{m}^{-2} \mathrm{~d}^{-1}$ at Faros and at the harbour, respectively (Table 1, Figs. 3a, b). All the Faros macroseep area, about $800 \mathrm{~m}^{2}$ of muddy soil without grass cover, emits fluxes in the order of $10^{3}-10^{5} \mathrm{mg} \mathrm{m}^{-2} \mathrm{~d}^{-1}$. The highest values are close to the vents that sometimes form small fires. The flux decreases down to tens of $\mathrm{mg} \mathrm{m}^{-2} \mathrm{~d}^{-1}$ at 90 $\mathrm{m}$ distance, along the flank of a grassy hill (Figs. 3a, 5). In the harbour, where the paved asphalt is shattered by the gas leakage, the fluxes are at a level of $10^{3}-10^{4} \mathrm{mg} \mathrm{m}^{-2} \mathrm{~d}^{-1}$ (Table 1 , Fig. 3b). 
Table 1. Methane microseepage fluxes.

\begin{tabular}{lccc}
\hline Location & Position & N. of measurements & Flux* $\left(\mathrm{mg} \mathrm{m}^{-2} \mathrm{~d}^{-1}\right)$ \\
\hline Killini & $\begin{array}{c}\text { on the border of bubbling pools } \\
\text { close to the main spring }\end{array}$ & 5 & from 40 to 185 \\
$>20 \mathrm{~m}$ from the spring & 3 & $700-2200-2520$ \\
& road $(>100 \mathrm{~m}$ from the spring) & 5 & from 60 to 320 \\
& wharf (duty-free shop) & 6 & from -5 to 50 \\
\hline Katakolo harbour & custom building & 1 & 165000 \\
& parking (holes in the pave) & 3 & $5600-4800-6900$ \\
& $>30 \mathrm{~m}$ far from the seeps & 2 & $57000-80000$ \\
\hline Katakolo Faros & macroseep area & 3 & $44-365-450$ \\
\hline & hill slope (90, 30, $10 \mathrm{~m}$ from seep) & 3 & from 6800 to 285000 \\
\hline
\end{tabular}

* The range of values is given for the sites in which more than 3 measurements were performed.

Table 2 shows the gas concentration in the vents. The Killini gas in the bubbling pools has about $80 \%$ of $\mathrm{CH}_{4}$ and $0.01 \%$ of $\mathrm{H}_{2} \mathrm{~S}$; Katakolo gas vents have around $90 \% \mathrm{CH}_{4}$ and $0.02 \% \mathrm{H}_{2} \mathrm{~S}$. In the Katakolo harbour soil, there is a $10 \mathrm{~cm}$ hole in the asphalt; here the methane gas concentration is at about $9 \%$. This concentration is within the range of methane explosiveness (generally 5 - 10\% in presence of oxygen). Offshore vents showed a methane concentration lower than that of the onshore vents; this is likely due to the quick exchange of gas between the bubbles and the seawater (Leifer and Patro 2002).

Table 2. Gas concentration in gas vents and soil-gas (\% v/v).

\begin{tabular}{cccc}
\hline \hline Location & & $\mathrm{CH}_{4}$ & $\mathrm{H}_{2} \mathrm{~S}$ \\
\hline Killini & Bubbles* & 80 & 0.01 \\
Katakolo offshore & Bubbles & 40 & 0.23 \\
& & & \\
Katakolo harbour & Soil-gas (10cm) & 9.3 & 0.005 \\
& Vent* & 85 & 0.02 \\
Katakolo Faros & Vent* & 94 & - \\
\hline
\end{tabular}

* On-site analyses by portable GC-FID $\left(\mathrm{CH}_{4}\right)$ and colorimetric tubes $\left(\mathrm{H}_{2} \mathrm{~S}\right)$. 
Table 3 shows the composition of the gas dissolved in the springs of Killini and Kaiafas. Also these waters are $\mathrm{CH}_{4}$ enriched with significant amounts of $\mathrm{H}_{2} \mathrm{~S}$. The concentrations obtained by on-site analyses are lower than laboratory results; this is reasonable and expected because the head-space gas extraction and equilibration in the field was likely incomplete, as generally occurs.

Over the soil surface, up to $50 \mathrm{~cm}$, the atmospheric air is generally $\mathrm{CH}_{4}$ enriched, with concentrations rising from 1.7 - $1.9 \mathrm{ppmv}$ (background) to tens of ppm throughout wide areas, up to hundreds ppmv as in the Katakolo harbour (Duty Free Shop and Custom buildings), and thousands ppmv at the Faros macroseep (Table 4; Figs. 3a, b). $\mathrm{H}_{2} \mathrm{~S}$ reaches 100 ppmv outside

Table 3. Composition of head-space gas from spring waters (\% v/v).

\begin{tabular}{lccc}
\hline \hline Location & & $\mathrm{CH}_{4}$ & $\mathrm{H}_{2} \mathrm{~S}$ \\
\hline Killini & spring & 10.01 & 3.50 \\
& spring* $^{*}$ & 8.1 & 1.9 \\
& bubbling pool & 17.21 & 2.08 \\
& bubbling pool* & 10.2 & 1.3 \\
Kaiafas & spring & 8.54 & 1.40 \\
& spring* & 6.8 & 0.7 \\
\hline
\end{tabular}

* On-site analyses by portable GC-FID $\left(\mathrm{CH}_{4}\right)$ and colorimetric tubes $\left(\mathrm{H}_{2} \mathrm{~S}\right)$.

Table 4. Gas concentration in the atmospheric air (ppmv)*

\begin{tabular}{|c|c|c|c|}
\hline Location & & $\mathrm{CH}_{4} * *$ & $\mathrm{H}_{2} \mathrm{~S}^{* * *}$ \\
\hline \multirow[t]{3}{*}{ Killini } & $<0.5 \mathrm{~m}$ above spring & (1) 1.9 & $(1)<0.2$ \\
\hline & $<0.5 \mathrm{~m}$ above bubbling pool & (1) 2.4 & (1) 1.4 \\
\hline & $<0.5 \mathrm{~m}$ at $>10 \mathrm{~m}$ from the spring & (5) $1.8-1.9$ & \\
\hline \multirow[t]{2}{*}{ Kaiafas } & Indoor (spring in the cave) & (2) $1.9-2.6$ & (1) $<0.2$ \\
\hline & Outdoor & (5) $1.7-1.8$ & \\
\hline \multirow[t]{3}{*}{ Katakolo harbour } & $<0.5 \mathrm{~m}$ above the pave (Duty Free shop) & (3) $9-2300$ & (1) 35 \\
\hline & $<0.5 \mathrm{~m}$ above the pave (Custom premise) & (2) $50-2800$ & (2) $80-100$ \\
\hline & $<0.5 \mathrm{~m}$ at $>10 \mathrm{~m}$ from the seeps & (5) $1.8-1.9$ & \\
\hline \multirow[t]{4}{*}{ Katakolo Faros } & $<0.1$ m above the soil (fire) & (2) $25000-28000$ & \\
\hline & (muddy soil) & (18) $50-5500$ & \\
\hline & (grass zone) & (11) $4-15$ & \\
\hline & (hill flank) & (5) $1.7-1.9$ & \\
\hline
\end{tabular}

* On-site analyses by portable sniffer-FID $\left(\mathrm{CH}_{4}\right)$ and colorimetric tubes $\left(\mathrm{H}_{2} \mathrm{~S}\right)$.

** Range of values; in brackets: number of points (about $0.2 \mathrm{~m}^{2}$ ) surveyed by the sniffer. 
the Customs' premises in Katakolo. $\mathrm{H}_{2} \mathrm{~S}$ was not detected $(<0.25 \mathrm{ppmv})$ in the air over the springs, as it remains mainly dissolved in the cold water due to its high solubility. Naturally, all the atmospheric values vary quickly and significantly with wind conditions.

\section{DISCUSSION}

Beyond the localised seeps (vents, bubbling pools) gas is released diffusely from the soil, without any visible manifestation. This microseepage is common and pervasive in all sedimentary hydrocarbon-prone basins of the world (Klusman et al. 1998; Etiope and Klusman 2002; Etiope 2005). In normal conditions (dry soil) methane flux from the soil is generally nil or negative (around 0 down to $-5 \mathrm{mg} \mathrm{m}^{-2} \mathrm{~d}^{-1}$ ) with gas moving from atmosphere to soil due to methanotrophic consumption. In areas with microseepage from natural gas reservoirs, the flux is positive reaching values of tens and hundreds of $\mathrm{m} \mathrm{m}^{-2} \mathrm{~d}^{-1}$ (up to thousand $\mathrm{mg} \mathrm{m}^{-2} \mathrm{~d}^{-1}$ in exceptional cases, such as in mud volcanoes and macroseepage zones; Etiope et al. 2004). The microseepage in the NW Peloponnesus ranges from $10^{1}$ to $10^{5} \mathrm{mg} \mathrm{m}^{-2} \mathrm{~d}^{-1}$ over an area $10^{4} \mathrm{~m}^{2}$. Both localised vents and microseepage produce anomalies in the atmospheric air composition. Water springs have very high $\mathrm{CH}_{4}$, and especially $\mathrm{H}_{2} \mathrm{~S}$, concentrations.

The seeps investigated lead to severe risks for people and buildings. The high content of methane can produce explosions or flames at the surface, especially when conditions suitable to form explosive mixtures $\left(5-10 \% \mathrm{CH}_{4}\right)$ take place, as we found to occur below the asphalt pavement in the Katakolo harbour. These conditions may have been the cause of the explosion which occurred in 1972 close to the Duty Free Shop building on the main wharf. Such a situation is particularly worrying since the harbour is highly frequented by tourists embarking or disembarking from cruise ships.

The Katakolo harbour is developing and growing, with new docks under construction (still in 2005). But the offshore methane emissions and shallow gas pockets can produce catastrophic "blow-outs" during drilling operations or damage to offshore structures. It is well known that gas into the marine sediments is a factor contributing to the initiation of sediment failures and enhances the process of liquefaction (Hovland and Judd 1988). Gas bubbles into the pore spaces of the seabed exert an upward buoyancy force on the sediments and if gas continues to migrate upwards and accumulates, pressure builds up and the shear strength of the sediments decreases. Under normal circumstances the increase of pore pressure will not result in a significant weakening of the bearing capacity of the sediments; but in the case of cyclic forces (earthquake, waves) the pore pressure equals the overburden pressure and the sediments lose their bearing capacity. Thus the gas charged sediments, when subjected to cyclic loads, can collapse more easily than the gas-free sediments. In the Katakolo harbour, the high seismicity of the area and the high percentage of gas into the pores of the sediments, as indicated by the intensive seepages, are considered important factors for triggering sediment failures. However, earthquake activity is a direct trigger for gas seepage (Field and Jennings 1987; Papatheodorou et al. 1993; Hasiotis et al. 1996). The positive correlation between seismic activity, gas migration and seepages over time is well documented in western Greece (Hasiotis et al. 1996). 
Hydrogen sulfide is the most dangerous and toxic geologic gas. It is classified as a chemical asphyxiant because it immediately chemically interacts with the blood's haemoglobin to block oxygen from being carried to the body's vital organs and tissues. Its characteristic rotten-egg smell is easy to detect at low concentrations, but at higher concentrations it paralyses the sense of smell. This can give someone a false sense of security when exposed to hydrogen sulfide. Generally, 10 ppmv cause eye irritation; 200 - 300 ppmv cause eye inflammation and respiratory tract irritation after 1 hour of exposition; 500 - 700 ppmv may lead to loss of consciousness and possible death in 30 - 60 minutes; 1000 ppmv give diaphragm paralysis on first breath and rapid asphyxiation. The $\mathrm{H}_{2} \mathrm{~S}$ levels of Katakolo seeps (hundreds to thousands ppmv) are really impressive and worrying. A close and prolonged exposure can be fatal. The atmospheric air $50 \mathrm{~cm}$ above the ground has on average tens of ppmv (eye irritant), but this level can increase if the pavement is shattered, if there are low barometric and wind forces, and in case of enhanced episodic degassing.

Further studies are going to assess the origin of $\mathrm{CH}_{4}$ and $\mathrm{H}_{2} \mathrm{~S}$, and their relationships with the local tectonics and stratigraphy, with special attention to the salt diapirism. A monitoring programme would be necessary to follow the evolution of the seepage and to assess possible precursor signals of enhanced degassing, blow-outs or explosions, eventually related to seismicity and gas pressure build-up under ground. In the meantime the local authorities have been alerted about these geological risks.

\section{REFERENCES}

Baxter, P. J., J. C. Baubron, and R. Coutinho, 1999: Health hazards and disaster potential of ground gas emissions at Furnas volcano, Sao Miguel, Azores.J. Volcanol. Geotherm. Res., 92, 95-106.

Brooks, M., and G. Ferentinos, 1984: Tectonics and sedimentation in the Gulf of Corinth and the Zakynthos and Kefallinia Channels, Western Greece. Tectonophys., 101, 25-54.

Etiope, G., 2005: Mud volcanoes and microseepage: the forgotten geophysical components of atmospheric methane budget. An. Geophysics, 48, 1-7.

Etiope, G., P. Carnevale, F. Gasparoni, M. Calcara, P. Favali, and G. Smriglio, 2002: Offshore hydrocarbon leakage: hazard and monitoring. In: Beranzoli, L., P. Favali, and G. Smriglio (Eds.), Science-Technology Synergy for Research in the Marine Environments: Challenges for the XXI Century. Develop. Mar. Technol., 12, 217-228. Elsevier, Amsterdam.

Etiope, G., A. Feyzullaiev, C. L. Baciu, and A. V. Milkov, 2004: Methane emission from mud volcanoes in eastern Azerbaijan. Geology, 32, 465-468.

Etiope, G., M. Guerra, and A. Raschi, 2005: Carbon dioxide and radon geohazards over a gasbearing fault in the Siena Graben (Central Italy). Terr. Atmos. Ocean. Sci., 16, 885896.

Etiope, G., and R. W. Klusman, 2002: Geologic emissions of methane to the atmosphere. Chemosphere, 49, 779-791. 
Field, M., and A. Jennings, 1987: Sea floor gas seeps triggered by a northern California earthquake. Mar. Geol., 77, 39-51.

Flores, M. R., 1998: Coalbed methane: from hazard to resource. Int. J. Coal Geol., 35, 3-26.

Hasiotis, T., G. Papatheodorou, N. Kastanos, and G. Ferentinos, 1996: A pock-mark field in the Patras Gulf (Greece) and its activation during the 14/7/1993 seismic event. Mar. Geol., 130, 333-344.

Hovland, M., and A. Judd, 1988: Seabed pockmarks and seepages. Impact on geology, biology and the marine environment. Graham and Trotman, 293 pp.

Hunt, J. M., 1996: Petroleum geochemistry and geology. W.H. Freeman and Co., New York, $743 \mathrm{pp}$.

Kamberis, E., N. Rigakis, S. Tsaila-Monopolis, C. Ioakim, and S. Sotiropoulos, 2000: Shallow biogenic gas-accumulations in Late Cainozoic sands of Katakolon peninsula, Western Greece. Geol. Soc. Greece Spec. Publ., 9, 121-138.

Klusman, R. W., M. E. Jakel, and M. P. LeRoy, 1998: Does microseepage of methane and light hydrocarbons contribute to the atmospheric budget of methane and to global climate change? Assoc. Petrol. Geochem. Explor. Bull., 11, 1-55.

Klusman, R. W., M. E. Leopold, and M. P. LeRoy, 2000: Seasonal variation in methane fluxes from sedimentary basins to the atmosphere: Results from chamber measurements and modelling of transport from deep sources. J. Geophys. Res. 105, 661-670.

Koukouvelas, I., A. Mpresiakas, E. Sokos, and T. Doutsos, 1996: The tectonic setting and earthquake ground hazards of the 1993 Pyrgos earthquake, Peloponnesus, Greece. $J$. Geol. Soc. London, 154, 39-49.

Lee, H. F., T. F. Yang, T. F. Lan, S. R. Song, and S. Tsao, 2005: Fumarolic gas composition of the Tatun Volcano Group, northern Taiwan. Terr. Atmos. Oceanic Sci., 16, 843-864.

Leifer, I., and R. K. Patro, 2002: The bubble mechanism for methane transport from the shallow sea bed to the surface: A review and sensitivity study. Cont. Shelf Res., 22, 2409-2428.

Lekkas, E., I. Fountoulis, and D. Papanikolaou, 2000: Intensity distribution and neotectonic macrostructure Pyrgos earthquake data (26 March 1993, Greece). Nat. Hazards, 21, 19-33.

Monopolis, D., and A. Bruneton, 1982: Ionian Sea (Western Greece): Its structural outline deduced from drilling and geophysical data. Tectonophys., 83, 227-242.

Papatheodorou, G., T. Hasiotis, and G. Ferentinos, 1993: Gas charged sediments in the Aegean and Ionian Seas, Greece. Mar. Geol., 112, 171-184.

Pecoraino, G., and S. Giammanco, 2005: Geochemical characterization and temporal changes in parietal gas emissions at Mt. Etna (Italy) during the period July 2000-July 2003. Terr. Atmos. Oceanic Sci., 16, 805-841.

Zelilidis, A., N. Kontopoulos, P. Avramidis, and D. Piper, 1998: Tectonic and sedimentological evolution of the Pliocene-Quaternary basins of Zakynthos island, Greece: case study of the transition from compressional to extensional tectonics. Basin Res., 10, 393-408. 